УДК 37.091.33- 027.22:004.358:577.1

Гребеник Людмила Іванівна

кандидат біологічних наук, доцент, доцент кафедри біофізики, біохімії, фармакології та бімолекулярної інженерії

Сумський державний університет, м. Суми, Україна

kineberg@rambler.ru

Прімова Людмила Олександрівна

кандидат біологічних наук, доцент, доцент кафедри біофізики, біохімії, фармакології та бімолекулярної інженерії

Сумський державний університет, м. Суми, Україна

primova.lyudmila@rambler.ru

Берест Олег Борисович

провідний фахівець кафедри комп'ютерних наук, секція інформатики

Сумський державний університет, м. Суми, Україна

Berest_Oleg@mail.ru

\title{
ВИКОРИСТАННЯ КОМП'ЮТЕРНОГО МОДЕЛЮВАННЯ ЛАБОРАТОРНИХ РОБІТ НА ПРАКТИЧНИХ ЗАНЯТТЯХ 3 БІОЛОГІЧНОЇ ХІМІЇ
}

\begin{abstract}
Анотація. У статті обгрунтована доцільність і показана можливість комп'ютерного моделювання експериментальних робіт під час проведення лабораторного практикуму 3 біологічної хімії для студентів-медиків. На прикладі лабораторної роботи «Кількісне визначення білірубіну у сироватці крові» визначені основні етапи і принципи створення віртуального «експерименту». Комп'ютерна модель роботи, що описана в статті, складається 3 декількох взаємопов'язаних послідовних сцен, які є імітацією реального експерименту. Основним програмним забезпеченням для створення віртуальної моделі були редактори FlashDevelop (IDE), написаний на мові програмування C\#, i Adobe Flash CS4 Professional. Використання авторами цієї й аналогічних віртуальних моделей було успішно апробовано на практичних заняттях з біологічної хімії для студентів-медиків. Визначені переваги дозволили розглянути можливість розробки інтерактивного архіву лабораторних робіт з біологічної хімії з подальшим їх розміщенням у репозитарії.
\end{abstract}

Ключові слова: інформаційні технології; віртуальні лабораторні роботи; біохімія; FlashDevelop (IDE); Adobe Design Premium CS4.

\section{1. ВСТУП}

Постановка проблеми. Біологічна хімія - одна 3 фундаментальних дисциплін у системі підготовки майбутніх лікарів, опанування якою є обов'язковим для формування клінічного мислення, розвитку умінь і навичок оцінки метаболічних процесів в організмі здорової людини і за умов розвитку патології. Для студента-медика $\epsilon$ важливим не тільки набуття грунтовних теоретичних знань, оволодіння ключовими поняттями і науковою термінологію, а й засвоєння практичних навичок і вмінь. Традиційно так склалося, що лабораторний практикум і експериментальна робота $\epsilon$ невід'ємною частиною навчального процесу під час вивчення природничих дисциплін і зокрема, біологічної хімії. Основним завданням лабораторного практикуму $\epsilon$ формування у студентів практичних навичок роботи з обладнанням і приладами, умінь аналізувати і зіставляти отримані результати з теоретичними даними. Усе це підвищує мотивацію до вивчення дисципліни і поглиблює розуміння біохімії, розвиває творче мислення, дозволяє ефективно застосовувати знання й уміння на практиці.

Під час організації лабораторного практикуму виникають проблеми, пов'язані 3 одночасним виконанням однієї лабораторної роботи великою групою студентів, що 
потребує значних матеріальних витрат на придбання хімічних реактивів, спеціалізованого обладнання і лабораторних приладів. Використання комп'ютерних технологій навчання дозволяє частково замінити реальний лабораторний практикум віртуальними лабораторними роботами. Це стає особливо актуальним у випадках, коли в дослідженнях використовують токсичні реагенти, дороге устаткування і реактиви, а також під час виконання довготривалих експериментів.

Аналіз останніх досліджень і публікацій. Одним із напрямків сучасної педагогіки вищої освіти, який активно розвивається, є впровадження інформаційних технологій. Відомо, що використання комп'ютерної техніки суттєво покращує якість процесу навчання [6]. Саме тому викладання більшості предметів у вищих навчальних закладах враховує цю сучасну тенденцію таі використовує на практиці.

Існують добре відомі й загально прийняти прийоми та методики використання інтерактивних технологій. Однак, оптимальне впровадження комп'ютерних технологій передбачає, у першу чергу, врахування специфіки вивчення кожного предмету i необхідність створення власних алгоритмів ефективного їх використання [1, с. 587590]. Однією з таких особливостей у вивченні біологічної хімії студентами вищих навчальних закладів, у тому числі медичних інститутів, є обов'язкова складова лабораторний практикум. Проведення лабораторних робіт на практичних заняттях 3 біологічної хімії є традиційним i, з дидактичної точки зору, беззастережно виправданим $[7$, c. $655-675]$.

3 упровадженням комп'ютерної техніки в навчальний процес з'явилися можливості змінити методичні підходи до проведення лабораторного практикуму. Нині в літературі активно обговорюється питання підвищення ефективності використання інтерактивних технологій у вивченні хімії, біологічної хімії та молекулярної біології [8, с. 28-54]. Не викликає сумнівів той факт, що комп'ютерні технології дозволяють оптимізувати, як процес викладання, так і процес вивчення біологічної хімії. Існуючі можливості комп'ютерного моделювання розв'язують низку дидактичних проблем вивчення хімічних наук, тому що стають ефективними інструментами візуалізації молекулярних процесів, ілюстрації окремих етапів або проведення лабораторної роботи в цілому, складання й реалізації алгоритмів виконання лабораторної роботи тощо.

Виходячи із сучасних тенденцій розвитку лабораторних експериментальних робіт в нашому університеті розроблені, створені та впровадженні в навчальний процес віртуальні лабораторні роботи з біологічної хімії.

Мета статті - на конкретному прикладі показати можливості використання сучасних інформаційних комп'ютерних технологій для створення віртуальних лабораторних робіт з біологічної хімії.

\section{2. МЕТОДИ ДОСЛІДЖЕННЯ}

Комп’ютерне моделювання лабораторної роботи здійснювали на основі логічно побудованих «сценаріїв», у яких були описані всі етапи і маніпуляції, що необхідні для візуалізації експерименту. За основу була взята стандартна методика визначення білірубіну i його фракцій у сироватці крові колориметричним діазометодом (за Йєндрашиком-Клеггорном-Грофом). Для реальної анімації всіх етапів експерименту враховувався дизайн приладів і обладнання, які наявні в біохімічній лабораторії і можуть бути використанні в реальному експерименті.

Для створення кінцевого продукту були використані декілька інтегрованих середовищ розробки. Основним програмним забезпеченням став редактор 3 безкоштовною ліцензією FlashDevelop. У цьому редакторі був розроблений структурний скелет лабораторної роботи. Значна кількість графічних елементів 
створена з використанням програми AdobeFlashCS4 Proffesional, як найбільш зручного інструменту для дизайну інтерактивного контенту. Формування необхідних даних у вигляді XML файлів здійснювали за допомогою текстового редактора AdobeDreamweaverCS4.

\section{3. РЕЗУЛЬТАТИ ДОСЛІДЖЕНЯ}

Метою створення віртуального лабораторного практикуму було підвищення ефективності використання робочого часу студентів на практичних заняттях i покращення загальної існуючої когнітивної схеми вивчення біологічної хімії. Крім того, однією 3 важливих мотивацій нашої роботи була економічна складова забезпечення лабораторного практикуму хімічними реактивами й обладнанням у сучасних умовах.

Створення комп'ютерних програм для моделювання лабораторних робіт було здійснено на основі «сценарію», який розроблений викладачами біологічної хімії 3 урахуванням послідовного виконання реального експерименту. Обов'язковим елементом кожної віртуальної моделі було виконання дослідження з використанням логічного алгоритму пошуку компоненту, який визначається.

Інтерфейс інтерактивних лабораторних робіт був розроблений у вигляді двовимірної моделі навчального кабінету студента-медика i став комп'ютерним шаблоном для цілого циклу робіт з біологічної хімії . На рис. 1 і рис. 2 , як приклад дизайну шаблону, наведені знімки екрану першої і четвертої сторінки (сцени) віртуальної лабораторної роботи «Кількісне визначення білірубіну в сироватці крові».

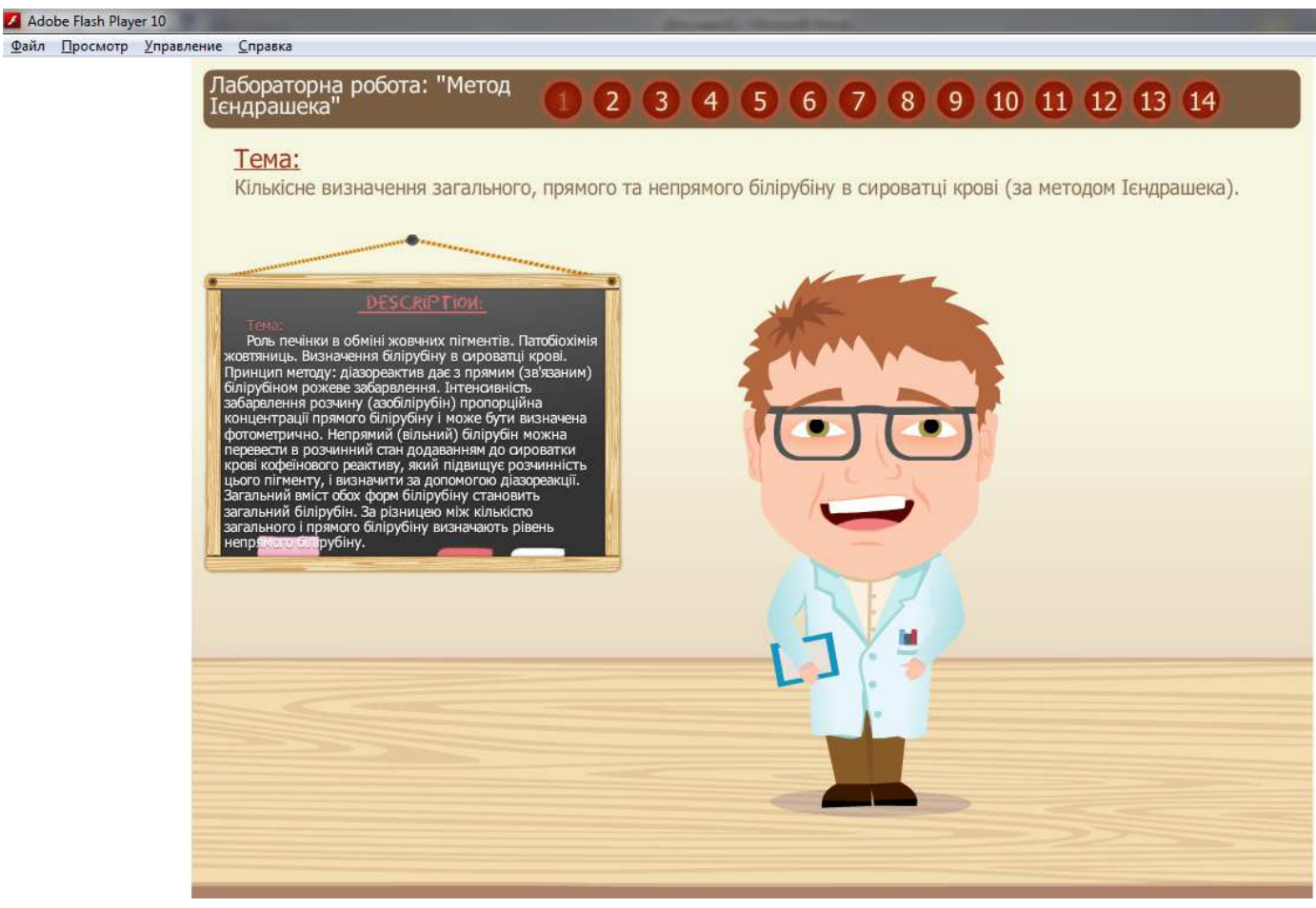

Рис. 1. Знімок екрану першої сторінки віртуальної лабораторної роботи «Кількісне визначення концентрачії білірубіну у сироватці крові»

Кожна віртуальна лабораторна робота складається 3 декількох взаємопов'язаних послідовних сцен, навігація якими здійснюється за допомого кнопок верхнього меню 
(рис. 1). Послідовність всіх етапів експерименту доступно описана на кожній сторінці й супроводжується підказками «віртуального студента». Перша сцена містить інформацію про назву лабораторної роботи і принцип методу, який використовується для визначення. На кожній наступній сторінці підказки «віртуального студента» дозволяють за допомогою стрілок здійснювати віртуальні хімічні маніпуляції (переміщення хімічного посуду, додавання хімічних реактивів, користування приладами, тощо), що є імітацією реального експерименту. Наприкінці віртуальної роботі студентам пропонується розрахувати або проаналізувати результат і зробити відповідні висновки.

У програмному виконанні лабораторна робота є контейнером (шаблоном), який залежно від обраної кнопки меню дозволяє завантажувати інтерактивні сцени. Кожна сцена виконана у вигляді .fla-файлу, який після компіляції створює .swf-файл, а той, у свою чергу, завантажується в шаблон. Попри це, дані, за допомогою яких визначається більшість властивостей елементів на робочій області, розміщені в XML-файлах, які додатково динамічно довантажуються для кожної сцени. Фізично лабораторна робота $€$ ієрархічною структурою папок і допоміжних файлів програми.

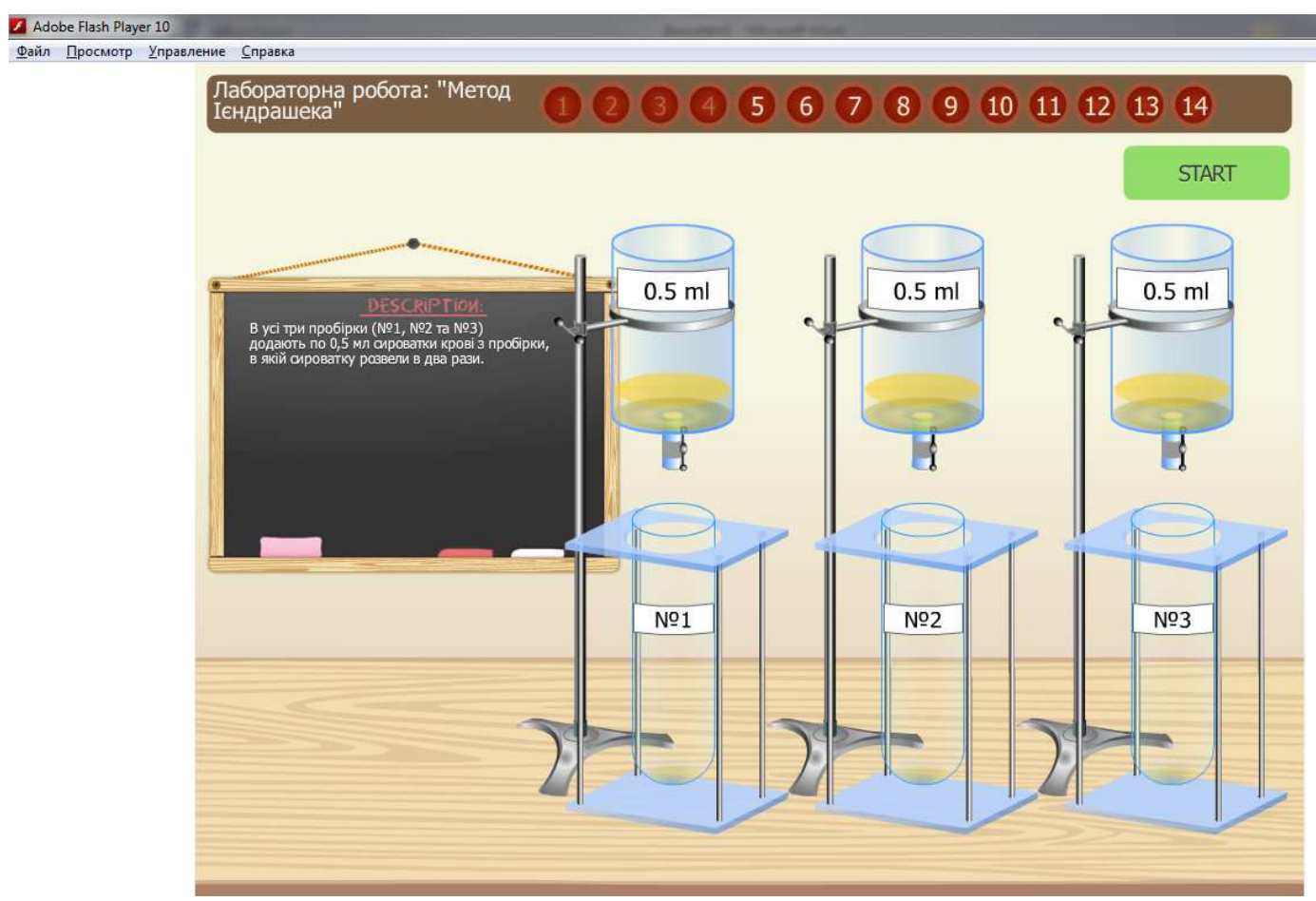

Рис. 2. Знімок екрану четвертої сторінки віртуальної лабораторної роботи «Кількісне визначення концентращії білірубіну у сироватщі крові»

Основним програмним забезпеченням для створення проекту віртуальних лабораторних робіт було середовище розробки та редактор FlashDevelop (IDE), написаний на мові програмування С\#, який дозволяє створювати Flash - програми за допомогою Flex SDK, MTASC або haxe. Кожна робоча сцена як .fla - файл була створена за допомогою Adobe Flash CS4 Proffesional. Під створенням сцени мається на увазі дизайн та декоративне розміщення елементів практичної лабораторної роботи (пробірок, колб тощо) та написання програмного коду для коректного функціонування в межах кожної сцени. А вже сам зв'язок між сценами реалізований за допомогою FlashDevelop 3 використанням принципів о'бєктно - орієнтованого програмування на мові ActionScript 3.0 [2-5; 10; 11 ]. Для створення додаткових XML - даних був 
використаний редактор Adobe Dreamweaver CS4, що дозволяє досить легко редагувати текстові файли.

Кожна лабораторна може бути реалізована як виконуваний портативний файл .ехе або як скомпільований .swf файл. Для коректної роботи в першому випадку достатньо розмістити файл у будь-якій директорії і запустити програму звичайним способом. У другому випадку необхідний встановлений Adobe Flash Player останньої версії (не нижче 9) або наявність браузера, який підтримує інтерактивну анімацію з інтегрованим програвачем swf-роликів. У даний час усі сучасні браузери відповідають цим вимогам (Opera, Google Chrome, Mozilla Firefox, Internet Explorer тощо). Даний підхід дає змогу завантажити інтерактивну роботу на сайт і надавати до неї доступ у дистанційному режимі.

Подальшим етапом розроблення може бути створення інтерактивного архіву робіт, який надає змогу вибирати необхідну роботу з репозитарію. Приклад наведений на рис. 3.

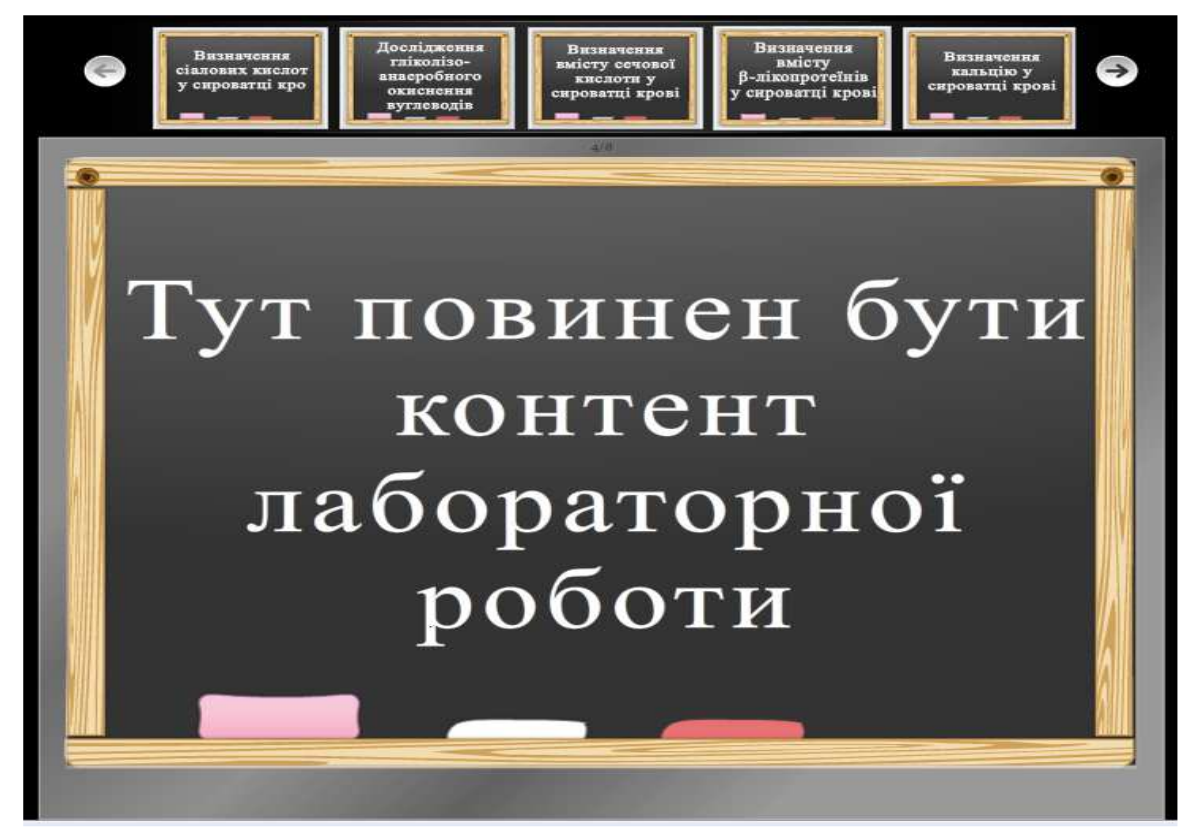

Рис. 3. Знімок екрану інтерактивного архіву

Наш досвід викладання біологічної хімії 3 використанням віртуального лабораторного практикуму дозволяє стверджувати, що комп'ютерне моделювання виконання деяких експериментів на практичних заняттях має суттєві переваги. Поперше, слід відзначити значну економію часу для виконання лабораторної роботи. Деякі етапи експерименту, що, наприклад, потребують довготривалої інкубації, у віртуальному режимі відбуваються за декілька хвилин і можуть бути обмежені лише швидкістю натискання кнопок клавіатури комп'ютера. Особливе значення такий підхід має під час виконання мультиетапних експериментів, реальне проведення яких в умовах лімітованого аудиторного часу досить часто буває неможливим. По-друге, звертає на себе увагу той факт, що інтерактивна візуалізація проведення довготривалого експерименту за короткий відтинок часу віртуальної роботи дозволяє оптимізувати сприйняття студентами інформації i покращити запам'ятовування послідовності етапів практичної реалізації виконання експерименту. Саме тому, перед виконанням деяких лабораторних робіт для ілюстрації поетапного виконання експерименту демонстрація віртуального варіанту може бути досить корисною. 
Доцільність і можливість комбінації віртуального й реального експериментів підтверджена на практиці у вищих навчальних закладах світу [9, с. 1-24].

\section{3. ВИСНОВКИ ТА ПЕРСПЕКТИВИ ПОДАЛЬШИХ ДОСЛІДЖЕНЬ}

Уведення віртуальних лабораторних робіт у процес викладання біохімії для студентів-медиків ми розглядаємо як ефективний крок у використанні сучасних інтерактивних форм надання інформації і як важливий елемент сучасних когнітивних технологій. Реалізація роботи щодо впровадження комп'ютерного моделювання в навчальний процес з біологічної хімії в нашому навчальному закладі враховує сучасні тенденції у вищій освіті, які передбачають поєднання існуючих технічних можливостей сучасних інформаційних технологій i організаційно-методичного забезпечення викладання предмету.

На нашу думку, до 40-50\% лабораторних робіт з біологічної хімії, що виконуються на практичних заняттях, можуть бути переведені у віртуальний формат або виконані з використанням комп'ютерного моделювання.

На теперішній час нами створена база «сценаріїв», за якими відтворені більше десятка віртуальних лабораторних робіт, що активно впроваджуються в навчальний процес на практичних заняттях з біохімії. Перспективним баченням у цьому напрямку $є$ розробка аналогічного практикуму для клініко-лабораторної діагностики 3 уведенням ситуаційних завдань клінічного спрямування (кейсів - cases), тобто з використанням елементів проблемно-орієнтовного навчання (PBL — problem-based learning). 3 урахуванням існуючої світової практики використання віртуальних клінічних завдань під час підготовки студентів - майбутніх лікарів за системою PBL, ми вважаємо, що наш досвід може бути корисним оскільки запропоновані форми візуалізації матеріалу здатні суттєво підвищити ефективність засвоєння практичних знань і навичок.

\section{СПИСОК ЛІТЕРАТУРИ}

1. Князева Е. М. Лабораторные работы нового поколения / Е. М. Князева // Фундаментальные исследования. - 2012. — № 6 (часть 3). - С. 587-590.

2. Лотт Дж. ActionScript 3.0. Сборник рецептов / Лотт Дж., Шалл Д., Питерс К. ; пер. с англ. - СПб. : Символ-Плюс, 2007. - 608 с.

3. Мук К. ActionScript 3.0 для Flash. Подробное руководство / Мук К. - СПб. : Питер, 2009. — 992 с.

4. Ульрих К. Adobe Flash CS3 Professional для Windows и Macintosh / Ульрих К.; пер. с англ. А. Слинкина. - М. : ДМК Пресс, 2009. - 568 с.

5. Braunstein R. ActionScript 3.0 bible / Braunstein R., Wright M., Noble J. — P. : Wiley Publishing, 2007. $-794 \mathrm{p}$.

6. Evans V. Cognitive Linguistics. An Introduction / V. Evans, M. Green. — Edinburgh U.P., 2006. — 864 p.

7. Hart C. What is the purpose of this experiment? Or can students learn something from doing experiments?/ [C. Hart, P. Mulhall, A. Berry, J. Loughran, R. Gunstone] // Journal of Research in Science Teaching. — 2000. — № 37(7). — P. 655-675.

8. Hofstein A. The laboratory in science education: foundation for the 21 st century/ A. Hofstein, V. N. Lunetta // Science Education. - 2004. - Vol. 88. — P. 28-54.

9. Ma J. Hands-on, simulated, and remote laboratories: A comparative literature review / J. Ma, J. V. Nickerson // ACM Computing Surveys. - 2006. — Vol. 38(3). - P. 1-24.

10. Shupe R. Learning ActionScript 3.0. A Beginner's Guide / Shupe R. - P. : OReilly, 2008. — 384 p.

11. Webster S. Foundation ActionScript 3.0 for Flash and Flex / Webster S., Yard T., McSharry S. - P. : FriendsofED, 2009. - $581 \mathrm{p}$. 


\title{
ИСПОЛЬЗОВАНИЕ КОМПЬЮТЕРНОГО МОДЕЛИРОВАНИЯ ЛАБОРАТОРНЫХ РАБОТ НА ПРАКТИЧЕСКИХ ЗАНЯТИЯХ ПО БИОЛОГИЧЕСКОЙ ХИМИИ
}

\section{Гребеник Людмила Ивановна}

кандидат биологических наук, доцент, доцент кафедры биофизики, биохимии, фармакологии и бимолекулярной инженерии

Сумский государственный университет, г. Сумы, Украина

kineberg@rambler.ru

\section{Примова Людмила Александровна}

кандидат биологических наук, доцент, доцент кафедры биофизики, биохимии, фармакологии и бимолекулярной инженерии

Сумский государственный университет, г. Сумы, Украина

primova.lyudmila@rambler.ru

\section{Берест Олег Борисович}

ведущий специалист кафедры компьютерных наук, секция информатики

Сумский государственный университет, г. Сумы, Украина

Berest_Oleg@mail.ru

\begin{abstract}
Аннотация. В статье обоснована целесообразность и показана возможность и перспективность компьютерного моделирования экспериментальных работ при проведении лабораторного практикума по биологической химии для студентов-медиков. На примере лабораторной работы «Количественное определение билирубина в сыворотке крови» определены основные этапы и принципы создания виртуального эксперимента. Компьютерная модель работы, которая описана в статье, состоит из нескольких взаимосвязанных последовательных сцен, которые являются имитацией реального эксперимента. Основным программным обеспечением для создания виртуальной модели были редакторы FlashDevelop (IDE), написанный на языке C\#, и Adobe Flash CS4 Professional. Использование авторами этой и аналогичных виртуальных моделей было успешно апробировано на практических занятиях по биологической химии для студентовмедиков. Указанные преимущества позволили рассмотреть возможность разработки интерактивного архива лабораторных работ по биологической химии с дальнейшим их размещением в репозитарии.
\end{abstract}

Ключевые слова: информационные технологии; виртуальные лабораторные роботы; биохимия; FlashDevelop (IDE); Adobe Design Premium CS4.

\section{USING OF COMPUTER SIMULATIONS OF LABORATORY WORK FOR PRACTICAL CLASSES ON BIOLOGICAL CHEMISTRY}

\section{Liudmyla I. Hrebenyk}

Ph.D. (biology), associate professor, assistant professor of biophysics, biochemistry, pharmacology and bimolecular engineering

Sumy State University, Sumy, Ukraine

kineberg@rambler.ru

\section{Liudmyla O. Primova}

$\mathrm{Ph}$.D.(biology), associate professor, assistant professor of biophysics, biochemistry, pharmacology and bimolecular engineering

Sumy State University, Sumy, Ukraine

primova.lyudmila@rambler.ru

\section{Oleh B. Berest}

Leading Specialist, Department of Computer Science, Informatics Section

Sumy State University, Sumy, Ukraine

Berest_Oleg@mail.ru 


\begin{abstract}
The expediency and possibility of computer simulations of experiments during the laboratory work in biological chemistry for medical students are shown in this paper. Basic stages and principles of virtual experiment creation were determined on the example of the laboratory work "Quantitative determination of serum bilirubin". The computer model of the work described in this article consist several interrelated consecutive scenes that imitate the real experiment. The basic software for creating of virtual models was editors FlashDevelop (IDE), written in C \#, and Adobe Flash CS4 Professional. Using of this and similar virtual models by the authors have been successfully tested on a practical training on biological chemistry for medical students. These advantages allowed to consider the possibility developing an interactive archive of laboratory works in biological chemistry with their further placement in the repository.
\end{abstract}

Keywords: information technology; virtual laboratory works; biochemistry; FlashDevelop (IDE); Adobe Design Premium CS4.

\title{
REFERENCES (TRANSLATED AND TRANSLITERATED)
}

1. Knjazeva E. M. Laboratory work of new generation / E. M. Knjazeva // Fundamental'nye issledovanija. — 2012. — № 6 (part 3). — S. 587-590. (in Russian).

2. Lott Dzh. ActionScript 3.0. Collection of recipes / Lott Dzh., Shall D., Piters K.; per. s angl. - SPb. : Simvol-Pljus, 2007. - 608 s. (in Russian).

3. Muk K. ActionScript 3.0 for Flash. Detailed guide / Muk K. — SPb. : Piter, 2009. — 992 s. (in Russian).

4. Ul'rih K. Adobe Flash CS3 Professional for Windows and Macintosh / Ul'rih K.; per. s angl. A. Slinkina. - M. : DMK Press, 2009. - 568 s. (in Russian).

5. Braunstein R. ActionScript 3.0 bible / Braunstein R., Wright M., Noble J. — P. : Wiley Publishing, 2007. - 794 p.(in English).

6. Evans V. Cognitive Linguistics. An Introduction / V. Evans, M. Green. — Edinburgh U.P., 2006. — 864 p. (in English).

7. Hart C. What is the purpose of this experiment? Or can students learn something from doing experiments?/ [C. Hart, P. Mulhall, A. Berry, J. Loughran, R. Gunstone] // Journal of Research in Science Teaching. - 2000. — № 37(7). — P. 655-675. (in English).

8. Hofstein A. The laboratory in science education: foundation for the 21 st century/ A. Hofstein, V. N. Lunetta // Science Education. - 2004. - Vol. 88. - P. 28-54. (in English).

9. Ma J. Hands-on, simulated, and remote laboratories: A comparative literature review /J. Ma, J. V. Nickerson // ACM Computing Surveys. — 2006. — Vol. 38(3). — P. 1-24. (in English).

10. Shupe R. Learning ActionScript 3.0. A Beginner's Guide / Shupe R. — P. : OReilly, 2008. — 384 p. (in English).

11. Webster S. Foundation ActionScript 3.0 for Flash and Flex / Webster S., Yard T., McSharry S. - P. : FriendsofED, 2009. — 581 p. (in English). 